\title{
ISOLASI DAN IDENTIFIKASI BAKTERI YANG TERDAPAT PADA SALURAN PENCERNAAN IKAN GURAMI (Osphronemus gouramy) DENGAN PEMBERIAN PAKAN KOMERSIL YANG BERBEDA
}

\section{ISOLATION AND IDENTIFICATION OF BACTERIAL IN THE DIGESTIVE ORGAN OF GURAMI FISH (Osphronemus gouramy) WITH DIFFERENT COMMERCIAL FEED}

\author{
Franch Dalahi, Sri Subekti dan Agustono \\ Fakultas Perikanan dan Kelautan Universitas Airlangga \\ Kampus C Mulyorejo - Surabaya, 60115 Telp. 031-5911451
}

\begin{abstract}
Based on the food habits, gurami is omnivorous fish that feed herbivorous carp tend consists of natural food and artificial feed (pellets). The feed is needed to support the growth and survival of Gurami. If feed is given in accordance with the eating habits of Gurami and contain high nutritional Gurami can then growth accelerated faster. Some types of bacteria found in the digestive tract of animals has an important role in order to improve feed utilization, fish health, and environmental quality improvement and microorganisms. In addition, some bacterial flora in the gastrointestinal tract plays an important role and produce several types of enzymes in the digestive tract may contribute to the metabolism of the host.

The purpose of this study was to determine the bacteria in the digestive tract of Gurami (Osphronemus gouramy) were given three different types of commercial feed. This study begins with a sampling of Gurami (Oshpronemus gouramy) of maintenance in the Faculty of Fisheries and Marine at Airlangga University in Surabaya and then do stage isolation and identification of bacteria in laboratory bacteria and Microbiology, Faculty of Veterinary Medicine, Airlangga University Surabaya. This study was conducted in July 2013. This research is a descriptive study, the method of solving the problem by describing the subject matter into a form that is easy to understand and based on facts.

Results of research on gurami fish that given by three different types of commercial feed, there are two types of bacteria that dominate in the digestive tract of carp, the Pseudomonas sp. and Serratia sp. Both types of bacteria has the potential to help the digestive system of gurami fish.

The result of this research are need for further research using the bacterium Pseudomonas sp. and Serratia sp. as probiotics.
\end{abstract}

Keywords : Gurami, Identification, Isolation, Digestive Organ, Pseudomonas sp., Serratia sp.

\section{Pendahuluan}

Ikan gurami (Osphronemus gouramy) merupakan salah satu komoditas unggulan ikan air tawar yang mudah dibudidayakan serta mempunyai nilai ekonomis yang tinggi. Perikanan budidaya, khususnya ikan gurami, selain berperan dalam pemenuhan kebutuhan gizi masyarakat, peningkatan pendapatan petani dan negara, juga penting dalam perluasan kesempatan kerja dan pertumbuhan agroindustri (Mahyuddin, 2009).

Tillman et al. (1998) menyatakan bahwa faktor-faktor yang mempengaruhi kecernaan pakan antara lain komposisi pakan dan jumlah pakan yang diberikan.Pakan gurami terdiri dari pakan alami dan pakan buatan (pellet). Pakan tersebut dibutuhkan untuk menunjang pertumbuhan dan kelangsungan hidup ikan gurami. Jika pakan yang diberikan sesuai dengan kebiasaan makan gurami dan mengandung gizi yang tinggi maka pertumbuhan ikan gurami dapat terpacu lebih cepat.

Beberapa jenis bakteri yang terdapat dalam saluran pencernaan hewan memiliki peran penting dalam rangka meningkatkan pemanfaatan pakan, kesehatan ikan, dan perbaikan mutu lingkungan dan mikroorganisme (Watson et al. 2008). Selain itu, beberapa bakteri flora pada saluran pencernaan memainkan peran yang cukup penting dan menghasilkan beberapa jenis enzim dalam saluran pencernaan yang kemungkinan turut berperan dalam metabolisme inang.

Pelczar dan Chan (1988) mengemukakan bahwa bakteri asli saluran pencernaan mempunyai hubungan mutualisme dengan inangnya, yaitu memanfaatkan inang sebagai tempat hidupnya. Keuntungan bagi inang adalah umumnya bakteri memakan sisa atau menggunakan bahan buangan, banyak bakteri usus dapat mensintesis vitamin, 
mensekresi enzim, dan membantu pencernaan nutrien, dan kehadiran bakteri asli cenderung menekan pertumbuhan bakteri patogen sehingga dapat melindungi inang terhadap penyakit serta merangsang fungsi kekebalan tubuh.

Tujuan penelitian ini adalah untuk mengetahui bakteri dalam saluran pencernaan ikan gurami (Osphronemus gouramy) yang diberi tiga jenis pakan komersial yang berbeda. Hasil dari penelitian ini diharapkan dapat memberikan informasi tentang bakteri dalam saluran pencernaan ikan gurami (Osphronemus gouramy) yang diberi tiga jenis pakan komersial yang berbeda.

\section{Materi dan Metode}

Penelitian ini dimulai dengan pengambilan sampel gurami (Oshpronemus gouramy) dari pemeliharaan di Fakultas Perikanan dan Kelautan di Universitas Airlangga Surabaya kemudian dilakukan tahap isolasi dan identifikasi bakteri di Laboratorium Bakteri dan Mikrobiologi Fakultas Kedokteran Hewan Universitas Airlangga Surabaya. Penelitian ini dilaksanakan pada bulan Juli 2013.

Alat-alat yang digunakan untuk isolasi dan identifikasi antara lain, inkubator, autoclave, pipet, erlenmeyer, alumunium foil, pembakar Bunsen, cawan Petri, neraca dengan ketelitian 0,1 g, gelas ukur, kapas, mikroskop binokuler, gelas objek, jarum ose.

Bahan-bahan yang digunakan dalam penelitian ini adalah organ pencernaan lambung, usus halus, usus besar, ikan gurami yang di ambil dari pemeliharaan di Fakultas Perikanan dan Kelautan di Universitas Airlangga Surabaya, media agar NA (Natrium Agar), SCA (Simmon's Citrate Agar), TSI (Triple Sugar Iron) agar,bahan untuk uji gula (glukosa,manitol, maltose, sukrosa, laktosa), bahan untuk uji pewarnaan Gram (crystal violet, lugol iodine, safranin, etil alkohol 95\%, dan aquades), $\mathrm{NaCl}$ fisiologis dan imersi.

Jenis penelitian ini adalah penelitian deskriptif, yaitu metode pemecahan masalah dengan menggambarkan obyek permasalahan ke dalam suatu bentuk yang mudah dimengerti dan berdasarkan fakta - fakta yang ada (Rosidi, 2005).

Sumber inokulan didapatkan dari saluran pencernaan gurami dari pemeliharaan di Fakultas Perikanan dan Kelautan di Universitas Airlangga Surabaya dengan cara mengeluarkan saluran pencernaan gurami yaitu lambung, usus halus, dan usus besar. Saluran pencernaan ditimbang kemudian digerus. Setiap $1 \mathrm{~g}$ saluran pencernaan diencerkan dengan $9 \mathrm{ml}$ larutan fisiologis $(\mathrm{NaCl} 0,85 \%)$ pada $\mathrm{pH}$ yang sesuai dengan $\mathrm{pH}$ dalam saluran pencernaan gurami 7 , dengan tujuan hanya bakteri yang membantu pencernaan yang dapat tumbuh dan berkembang pada $\mathrm{pH}$ tersebut. Sampel hasil pengenceran kemudian ditumbuhkan pada media agar NA. Selanjutnya isolat diinkubasi selama 24 jam dalam inkubator pada suhu $35{ }^{\circ} \mathrm{C}$. Pada hari berikutnya dilihat pertumbuhannya dan dipilih satu koloni yang dominan dan letaknya yang berjauhan dengan koloni lainnya untuk ditanam kembali pada media NA sampai beberapa kali ulangan minimal tiga kali ulangan, kemudian ditemukan isolat murni

Metode identifikasi bakteri yang dilakukan adalah dengan cara konvensional, dengan membandingkan bakteri yang sedang diidentifikasi dengan bakteri yang telah teridentifikasi sebelumnya. Bila tidak terdapat bakteri yang ciri-cirinya $100 \%$ serupa, maka dilakukan pendekatan terhadap bakteri yang memiliki ciri-ciri yang paling menyerupai. Hasil uji dalam identifikasi dibandingkan dengan ciriciri bakteri yang diuraikan oleh Cowan and Steel's (1974). Serangkaian uji yang digunakan dalam identifikasi bakteri meliputi pemeriksaan morfologi, pewarnaan gram, dan uji biokimia antara lain : uji O/F, uji SCA, uji katalase, uji motilitas, produksi indol, uji TSIA dan uji gula (Beisher, 1991 dalam Kusdarwati dan Sudarno, 2011).

\section{Hasil dan Pembahasan}

Secara alamiah, mikroba terdapat dalam bentuk campuran dari berbagai jenis. Untuk mempelajari sifat pertumbuhan, morfologi dan sifat fisiologis mikroba, maka masing-masing mikroba tersebut harus dipisahkan satu dengan yang laimya, sehingga terbentuk kultur murni, yaitu suatu biakan yang terdiri dari sel-sel satu spesies atau satu galur mikroba (Fardiaz 1989). Setiap koloni yang tumbuh secara dominan dari setiap sampel pencernaan ikan gurami diambil dan ditumbuhkan kembali pada media NA untuk digunakan pada tahap identifikasi.

Pengamatan ciri-ciri tersebut, dibandingkan dengan ciri-ciri bakteri yang diuraikan oleh Cowan and Steel's Manual for the Identification of Medical Bacteria. Berdasarkan dari serangkaian pengamatan koloni bakteri, pewarnaan Gram, dan uji biokimia didapatkan bakteri sebagai berikut:

Bakteri yang mendekati genus ini mempunyai ciri-ciri morfologi yaitu: warna koloni agak kekuningan, termasuk bersifat Gram negatif, dan dalam kelompok sel 
Tabel 1. Identifikasi pada lambung.

\begin{tabular}{|c|c|c|c|}
\hline Jenis Pengujian & $\mathrm{P} 1$ & P2 & P3 \\
\hline $\begin{array}{cl}\text { Koloni: } & \\
\text { - } & \text { Warna } \\
\text { - } & \text { Bentuk elevasi }\end{array}$ & $\begin{array}{l}\text { Putih kekuningan } \\
\text { Cembung }\end{array}$ & $\begin{array}{c}\text { Krem } \\
\text { Cembung }\end{array}$ & $\begin{array}{c}\text { Putih kekuningan } \\
\text { Cembung }\end{array}$ \\
\hline & + & + & + \\
\hline \multicolumn{4}{|l|}{ Memproduksi: } \\
\hline • Indol & - & - & - \\
\hline - Katalase & + & + & + \\
\hline $\mathrm{O} / \mathrm{F}$ & - & $\mathrm{O}$ & - \\
\hline TSIA & K/K;-;- & A/A;-;- & $\mathrm{K} / \mathrm{K} ;-;-$ \\
\hline SCA & + & + & + \\
\hline \multicolumn{4}{|l|}{ UJI GULA: } \\
\hline - Glukosa & - & + & - \\
\hline - Manitol & - & + & - \\
\hline - Maltosa & - & + & - \\
\hline - Sukrosa & & + & - \\
\hline - Laktosa & & + & \\
\hline
\end{tabular}

Tabel 2. Identifikasi pada usus halus

\begin{tabular}{|c|c|c|c|}
\hline Jenis Pengujian & $\mathrm{P} 1$ & $\mathrm{P} 2$ & P3 \\
\hline $\begin{array}{c}\text { Koloni: } \\
\text { • Warna } \\
\text { - }\end{array}$ & $\begin{array}{l}\text { Putih kekuningan } \\
\text { Cembung }\end{array}$ & $\begin{array}{l}\text { Putih kekuningan } \\
\text { Cembung }\end{array}$ & $\begin{array}{c}\text { Putih kekuningan } \\
\text { Cembung }\end{array}$ \\
\hline Motilitas & + & + & + \\
\hline Memproduksi: & & & \\
\hline - Indol & - & - & - \\
\hline - Katalase & + & + & + \\
\hline $\mathrm{O} / \mathrm{F}$ & - & - & - \\
\hline TSIA & $\mathrm{K} / \mathrm{K} ;-;-$ & $\mathrm{K} / \mathrm{K} ;-;-$ & $\mathrm{K} / \mathrm{K} ;-;-$ \\
\hline SCA & + & + & + \\
\hline UJI GULA: & & & \\
\hline - Glukosa & - & - & - \\
\hline - $\quad$ Manitol & - & - & - \\
\hline - Maltosa & - & - & - \\
\hline - $\quad$ Sukrosa & 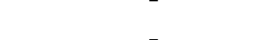 & 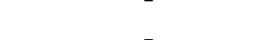 & - \\
\hline - Laktosa & & & \\
\hline
\end{tabular}

berbentuk batang dan lurus dengan ukuran 0,5$1,0 \times 1,5-5,0 \mu \mathrm{m}$. Bersifat fakultatif, uji katalase positif, motil, suhu optimum pertumbuhan pada $30-37^{\circ} \mathrm{C}$ dan tumbuh baik pada $\mathrm{NaCl} 3-7 \%$. Bakteri Pseudomonas sp. ada yang bersifat patogen dan ada yang bersifat menguntungkan bagi organisme lain. Effendi (2002) mengemukakan bahwa bakteri dari genus Pseudomonas sp dari spesies Pseudomonas bromoutilis ini memproduksi antibiotic 2, 3, 4 tribromo-5 (I, hidroksi-2, 4,-dibromophenil)pyrole. Zat ini bersifat menghambat perkembangan bakteri patogen seperti: Staphylococcus aureus, Streptococcus pneumonia, Streptococcus pyogenes, dan Microbacterium tubercolosis.

Serratia sp. adalah jenis bakteri Gram negatif, dari family Enterobactericeae. Bakteri ini berbentuk batang pendek dengan ukuran 0,5$0,8 \times 1,5-5,0 \mu \mathrm{m}$. Uji katalase positif, motil, suhu optimum pertumbuhan pada $30-37^{\circ} \mathrm{C}$. Bakteri ini merupakan bakteri fakultatif anaerobik yang tidak terlalu membutuhkan oksigen. Serratia marcescens dapat menghasilkan beberapa enzim hidrolitik seperti protease, kitinase, nuclease, dan lipase (Flyg et al., 1983). Berdasarkan penelitian yang telah dilakukan oleh Flyg pada tahun 1983 di Universitas Stockholm, strain S. marcescens 
Tabel 3. Identifikasi pada usus besar

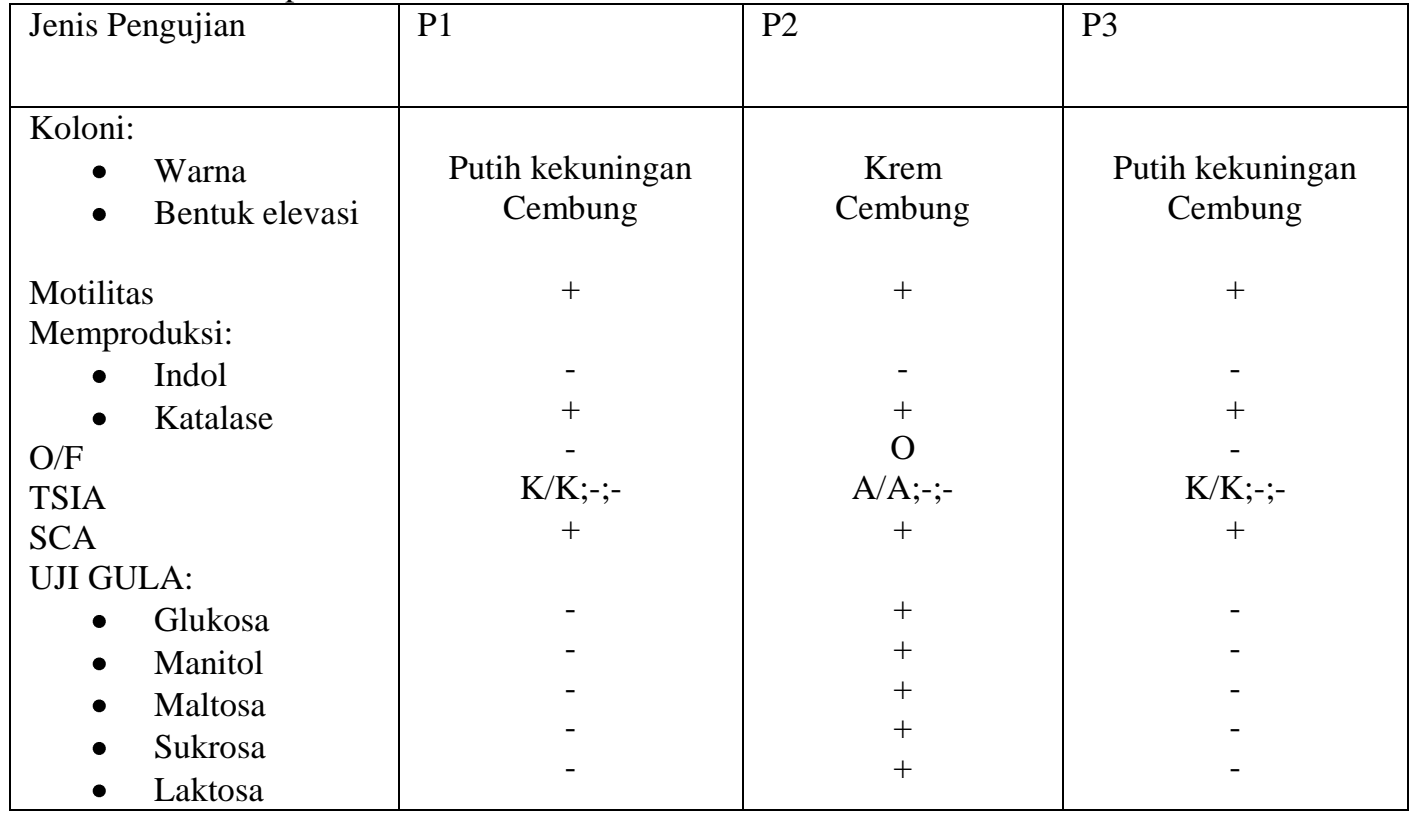

Keterangan tabel :

TSIA = K/K;-;- = Alkalis/alkalis; tidak terdapat gas; tidak terdapat $\mathrm{H}_{2} \mathrm{~S}$

TSIA = A/A;-;- = Asam/asam; tidak terdapat gas; tidak terdapat $\mathrm{H}_{2} \mathrm{~S}$

$\mathrm{O}=$ Oksidatif

$(+)=$ Positif $;(-)=$ Negatif

P1, P2, P3 = Jenis pakan

Tabel 4. Jenis Bakteri di Dalam Saluran Pencernaan Ikan Gurami Dengan Pemberian Pakan Komersil yang Berbeda.

\begin{tabular}{|c|c|c|c|}
\hline Jenis pakan & Bakteri pada lambung & $\begin{array}{c}\text { Bakteri pada } \\
\text { usus halus }\end{array}$ & $\begin{array}{c}\text { Bakteri pada } \\
\text { usus besar }\end{array}$ \\
\hline $\begin{array}{l}\text { Pakan A } \\
\text { Pakan B } \\
\text { Pakan C }\end{array}$ & $\begin{array}{l}\text { Pseudomonas sp. } \\
\text { Serratia } \mathrm{sp} \\
\text { Pseudomonas } \mathrm{sp} .\end{array}$ & $\begin{array}{l}\text { Pseudomonas sp. } \\
\text { Pseudomonas sp. } \\
\text { Pseudomonas sp. }\end{array}$ & $\begin{array}{l}\text { Pseudomonas } \mathrm{sp} . \\
\text { Serratia } \mathrm{sp} . \\
\text { Pseudomonas } \mathrm{sp} .\end{array}$ \\
\hline
\end{tabular}

yang diisolasi dari serangga sering kali memproduksi protease. Berbagai jenis bakteri seperti Bacillus sp., Lactobacillus sp., Pseudomonas sp., Clostridium sp. dan Serratia sp. merupakan penghasil enzim protease yang berpotensi. (Rao et al., 1998).

Pada lambung ikan yang diberi pakan A dan $\mathrm{C}$ hasil identifikasi terdapat jenis bakteri yang sama yaitu Pseudomonas sp, pada lambung ikan yang diberi pakan B hasil identifikasi terdapat jenis bakteri Serratia sp.. Pencernaan pada ikan dimulai pada lambung, pakan yang masuk melalui mulut ditampung pada lambung setelah itu diaduk dan dimulai proses pencernaan kimia di dalam lambung. Menurut Triastuti dkk. (2009) bahwa lambung merupakan tempat pengumpulan makanan sebelum dicerna dengan sebenarnya. Pencernaan kimiawi dilakukan di lambung.
Pengadukan makanan di dalam lambung terjadi dengan adanya gelombang-gelombang kecil yang terjadi setiap 20 detik.

Bakteri Pseudomonas sp. dapat memproduksi enzim protease, lipase, dan amylase, sehingga dapat membantu proses pencernaan yang berlangsung di lambung. Seperti yang dikatakan oleh Hardianto (2010) bahwa Pseudomonas sp. juga dapat menguraikan protein, karbohidrat dan senyawa organik lain menjadi $\mathrm{CO}_{2}$, gas amoniak, dan senyawa lain yang lebih sederhana. Serratia sp. dapat memproduksi enzim protease, sehingga dapat membantu proses pencernaan di dalam lambung ikan. Berdasarkan penelitian yang telah dilakukan oleh Flyg pada tahun 1983 di Universitas Stockholm, strain S. marcescens yang diisolasi dari serangga sering kali memproduksi protease. 
Usus merupakan segmen yang terpanjang dari saluran pencernaan dan berfungsi untuk penyerapan nutrisi pakan yang telah diolah dilambung. Pendapat yang sama dikatakan oleh Triastuti dkk. (2009) bahwa usus merupakan segmen yang terpanjang dari saluran pencernaan. Usus adalah tempat penyerapan utama dari makanan yang telah diolah di lambung.

Hasil dari identifikasi bakteri yang terdapat pada usus halus yang diberi pakan A, $\mathrm{B}$, dan $\mathrm{C}$ terdapat jenis bakteri yang sama yaitu Pseudomonas sp.. Usus besar yang diberi pakan A dan PCjuga terdapat jenis bakteri Pseudomonas sp., usus besar yang diberi pakan B terdapat jenis bakteri Serratia sp. Bakteri jenis Pseudomonas sp. dan Serratia sp. yang terdapat pada usus membantu penyerapan nutrisi, karena Pseudomonas sp. dan Serratia sp. dapat menghasilkan enzim protease. Pendapat ini didukung oleh Rao et al. (1998) bahwa bakteri seperti Bacillus sp., Lactobacillus sp., Pseudomonas sp., Clostridium sp. dan Serratia sp. merupakan penghasil enzim protease yang berpotensi.

Dengan adanya bakteri Pseudomonas sp. dalam saluran pencernaan ikan, dapat menekan pertumbuhan bakteri patogen. Penelitian sebelumnya telah dilakukan oleh Pradana dkk. (2010) bahwa aplikasi Pseudomonas sp. pada pencernaan ikan bandeng (Chanos chanos Forskal) dapat menekan pertumbuhan bakteri patogen di dalam usus ikan.

\section{Kesimpulan}

Kesimpulan pada penelitian ini adalah : terdapat jenis bakteri Pseudomonas sp. di dalam saluran pencernaan pada ikan yang diberi pakan A. Terdapat jenis bakteri Pseudomonas sp. dan Serratia sp. di dalam saluran pencernaan pada ikan yang diberi pakan B. Terdapat jenis bakteri Pseudomonas sp. di dalam saluran pencernaan pada ikan yang diberi pakan C. Perlu adanya penelitian lebih lanjut untuk menggunakan bakteri Pseudomonas sp. dan Serratia sp. sebagai kandidat probiotik.

\section{Daftar Pustaka}

Abbas, S. D. 1995. Pakan Ikan Alami. Kanisius. Yogyakarta. Hal 87.

Anhar, M., Henry, K. S., Aradhita, D., Sari, S., Hazrina, A. 2008. Cara Makan Ikan Nila (Oreochromis niloticus) dan ikan Nilem (Osteochilus hasselti). Program Kreativitas Mahasiswa Istitut Pertanian Bogor. Bogor.
Aslamyah S. 2006. Penggunaan Mikroflora Saluran Pencernaan Sebagai Probiotik Untuk Meningkatkan Pertumbuhan dan Kelangsungan Hidup Ikan Bandeng. Disertasi : Institut Pertanian Bogor. Hal 31.

Effendi, I. 2002. Probiotics for Marine Organism Disease Protection. Pekanbaru : Fakultas Perikanan dan Ilmu kelautan Universitas Riau.

Fardiaz, S. 1989. Petunjuk Laboratorium. Analisis Mikrobiologi Pangan. Bogor: Pusat Antar Universitas Pangan dan Gizi, Direktorat Jenderal Pendidikan Tinggi, Departemen Pendidikan dan Kebudayaan, Institut Pertanian Bogor.

Flyg, C. dan Xanthopoulos, G. K. 1983. Insect Phatogenic Properties of S. marcescens Passive and Active Resistance to Insect Immunity Studied with ProteaseDeficient and Phage-Resistance Mutants. Journal of General Microbiology 129: 453-464.

Hardhianto, M. D. 2010. Efektifitas Bakteri Pseudomonas sebagai Pengurai Bahan Organik (Protein, Karbohidrat, Lemak) pada Air Limbah Pembenihan Ikan Lele Dumbo (Clarias sp.) Sistem Resirkulasi Tertutup. Fakultas Perikanan dan Kelautan Universitas Airlangga. Surabaya.

Irianto, A. 2003. Probiotik Akuakultur. Gadjah Mada University Press. Yogyakarta. Hal 125.

Khairuman. dan K. Amri. 2002. Membuat Pakan Ikan Konsumsi. Agromedia Pustaka. Jakarta. Hal 45.

Kusdarwati, R dan Sudarno. 2011. Petunjuk Pratikum Analisis Penyakit Ikan I. Budidaya Perairan. Fak. Perikanan dan Kelautan. Universitas Airlangga. Surabaya.

Mahyuddin dan Kholish. 2009. Panduan Lengkap Agribisnis Ikan Gurami. Depok. Penebar Swadaya. Hal 251.

Pelczar, M. J. Jr. and Chan, E. C. S. 1986. Dasar-Dasar Mikrobiologi. (diterjemahkan dari bahasa Inggris oleh Hadioetomo, R.S., T. Imas, S.S. Tjitrosomo \& S.L. Angka). Volume ke1,2. UI Press, Jakarta.

Pradana, M. S.; Suprapto, H.; dan Sasmita, R. 2010. Aplikasi Pseudomonas untuk Menekan Pertumbuhan Bakteri Patogen di dalam Pencernaan Juvenil Ikan Bandeng (Chanos chanos Forskal) dan Penguraian Bahan Organik. 
Fakultas Perikanan dan Kelautan Universitas Airlangga. Surabaya.

Rao, M. B.; Tanksale, A. M.; Ghatge, M.S.; and Deshpande, V. V. 1998. Molecular and biotechnological aspects of microbial protease. Microb. Mol. Biol. Rev. 62: 1092-2172.

Rosidi, I. 2005. Sukses Menulis Karya Ilmiah Suatu Pendekatan Teori dan Praktik. Pustaka Sidogiri. Pasuruan. Hal 128.

Tillman, A.D., H. Hartadi, S. Reksohadiprodjo, S. Prawirokusumo, dan S. Lebdosukojo, 1998. Ilmu Makanan Ternak Dasar. Cetakan ke-4. Gadjah Mada University Press, Yogyakarta.
Triastuti, J., Sulmartiwi, L., dan Dhamayanti, Y. 2009. Buku Ajar Ichtyologi. Fakultas Perikanan dan Kelautan Universitas Airlangga. Surabaya.

Watson, K, A., Kaspar, H., Lategan, M.J., Gibson, L. 2008. Probiotics in aquaculture: The need, principles and mechanisms of action and screening processes. Aquaculture, Vol. 274. No.1, pp.1-14.

Yasoda, H, N., Z. Chi and Z, K, Ling. 2006. Probiotics and Sea Cucumber Farming. SPC Beche-de-mer Information Bulletin 24:45-48 